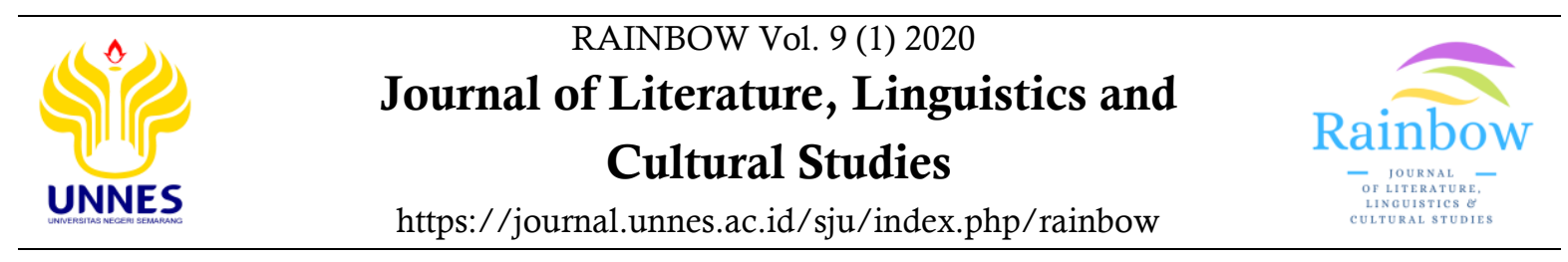

\title{
Strategies Used to Translate Idiomatic Expressions in "A Walk to Remember" into Indonesian and The Resulted Equivalence
}

\author{
Wayan Angguntur Nur Salamah ${ }^{\bowtie}$, Rudi Hartono, Bambang Purwanto \\ English Department, Faculty of Languages and Arts, Universitas Negeri Semarang, Indonesia
}

\begin{tabular}{|c|c|}
\hline Article Info & Abstract \\
\hline Article History: & \multirow{8}{*}{$\begin{array}{l}\text { This study is conducted to analyze the translation strategies used to translate the } \\
\text { idiomatic expressions in the novel "A Walk to Remember" into Indonesian, to } \\
\text { analyze the degree of equivalence of the Indonesian translation, and to find out } \\
\text { the relation between the strategy used and the degree of equivalence. The } \\
\text { translation strategies used in this study are proposed by Baker while the degrees } \\
\text { of equivalence are analyzed by using Bell's theory. This research belongs to } \\
\text { descriptive research using qualitative method to describe the objectives of this } \\
\text { study. The data are analyzed by comparing the idioms in the English version to } \\
\text { the Indonesian translation. After the data are identified, they are examined to } \\
\text { find out the relation between the strategies used and the degree of equivalence. } \\
\text { The findings of the analysis are: (1) four strategies were used to translate idioms } \\
\text { in the novel A Walk to Remember into Indonesian, (2) in terms of degree of } \\
\text { equivalence, it was found that most of the data were identified into fully } \\
\text { equivalent translation, (3) in the relation between translation strategies used and } \\
\text { the degree of equivalence, it was revealed that the translation strategies used } \\
\text { mostly produce fully equivalent with complete meaning. }\end{array}$} \\
\hline Received & \\
\hline 6 March 2020 & \\
\hline Approved & \\
\hline 8 April 2020 & \\
\hline Published & \\
\hline 30 April 2020 & \\
\hline $\begin{array}{l}\text { Keywords: a walk to remember, } \\
\text { degree of meaning equivalance, } \\
\text { idioms translation strategies }\end{array}$ & \\
\hline
\end{tabular}

(C) 2020 Universitas Negeri Semarang 


\section{INTRODUCTION}

Translation is a great way to help people broaden their knowledge by delivering the information from English into their native language. In order to do that, a translator should consider that the readers of their translation products must feel like they are reading the original source. Therefore, a translator must provide a good translation. However, translating is not an easy task to do. According to Catford (1965), translation may be defined as "the replacement of textual material of one language, Source Language (SL), by equivalent textual material in a Target Language (TL)" (p.20). Larson (1984) also defines that the goal of a good translator is to translate idiomatically, by means of making many adjustments in the forms. In other words, the translator's goal should be to reproduce a text in the target language which communicates the same message as the source language but using the natural grammatical and lexical choices of the target language. (p.15)

In the process of translating a novel, a translator is not only challenged in terms of how well he masters both languages, but also how well he knows the cultural backgrounds between those countries. The translator should understand some aspects which are related to the translation process. The translator needs to know about the culture and the tradition of both languages and another aspect to be considered to produce a good translation. A good translation is not only to transfer the meaning, and so as translating a novel. Translating a novel is not an easy job because it is not only transferring the message but entertaining and educating the reader. Larson (1984) states that the goal of a good translator is to translate idiomatically, by means of making many adjustments in the form. In other word, the translator's goal is the ability to reproduce a text in the target language which communicates the same idea or message as the source language but use the natural grammatical and lexical choices of the target language.
There are some problematic factors that will be faced by the translator while translating an English novel, such as style, meaning, dictions, imagery, syntax, proverbs and idioms. Idiomatic expressions are often found in novels. The idiomatic expressions contain connotative meanings because they are categorized into literary words or terms that have denotative meanings. Therefore, the translator must be careful in translating idiomatic expressions because he needs to use some different strategies to translate and deliver the same meaning between the source language and the target language.

There are several studies related to strategies used in translating English idioms into Indonesian and degree of meaning equivalence. Saputri (2014) investigated the strategy used in translating idioms in Stephanie Meyer's Breaking Dawn. In her study, based on the result of each strategy, the translation strategies by paraphrase and complete meaning equivalence are the mostly used in her study. Winarto and Tanjung (2015) analyzed the strategy used in translating idiomatic expressions in Transformer III-Dark of The Moon and their degrees of meaning equivalence. Related to the translation strategies applied in translating idioms, it was found that translation by paraphrasing was most frequently used. And related to the degrees of meaning equivalence of the translated idiomatic expressions, 185 units of data were considered to be equivalent. Imanudin (2018) also analyzed the strategy used in translating idioms in Nabokov's Lolita and their degree of meaning equivalence. The result shows that most of the idiom in the source text are translated into equivalent meaning. This is because most of the idioms are translated by paraphrase and as the result, the meanings of idioms can be successfully transferred into target language.

The aims of this study are to analyze the translation strategies used to translate idiomatic expressions in the novel "A Walk to Remember" into Indonesian, the degree of equivalence of the Indonesian translation, and to find out the relation between the strategy used and the degree 
of equivalence. Therefore, theoretically, this study is expected to provide input regarding translation strategies and how these strategies are related to the degree of equivalence of the translation, especially when the translation is focused on idiomatic expressions in a literary work. Practically, this study is supposed to provide knowledge and information for translators and assist them in improving their skill in translating literary works from English to Indonesia. Also, this study could be used as a reference for other research in the future that has a similar topic.

\section{METHODS}

This research uses a descriptive method which is usually used for collecting, classifying and analyzing the data, and then arranging the conclusion about the accuracy of translated idiomatic expressions in the Indonesian translation of the novel $A$ Walk to Remember. The research is also supported by a qualitative method to show the research findings in a percentage. The object of this study is the novel $A$ Walk to Remember both in original version and its Indonesian translation.

The writer collects the data and analyzes the data and draws the conclusion based on the data which were taken from the novel. The data were taken from the novel $A$ Walk to Remember both in English original version and its Indonesian translation. The data were written text in the form of words, phrases, clauses and sentences in the novel. These data were compared in order to get the answers of the objectives of the study. Then, the data were analyzed and classified into categories that related to the translation strategies and degree of equivalence between English version and Indonesian translation of the novel by using Baker's theory and Bell's theory. Finally, the data were counted to find out the most dominant translation strategies and degree of equivalence.

In this study, the data were identified by using Baker's strategies of translation and Bell's classification of degree of equivalence.

\section{RESULTS AND DISCUSSIONS}

The Realization of Translation Strategies in Translating Idiomatic Expressions

There are 297 idioms found in the novel. According to the result of the analysis, it is found that four strategies of translation proposed by Baker (1992) are used to translate the idioms, they are: using idiom of similar meaning form (ISMF), using idiom of similar meaning but dissimilar form (ISMDF), translation by paraphrase (TP) and translation by omission (TO). The analysis of the strategies used for translating idioms can be seen in the table below.

Table 1. Frequency of Strategy Usage for Idiomatic Expressions

\begin{tabular}{llll}
\hline No. & Strategy & $\begin{array}{l}\text { Frequen } \\
\text { cy }\end{array}$ & $\begin{array}{l}\text { Percenta } \\
\text { ge }\end{array}$ \\
\hline 1. & TP & 220 & $74.07 \%$ \\
2. & ISMDF & 60 & $20.20 \%$ \\
3. & TO & 12 & $4.04 \%$ \\
4. & ISMF & 6 & $2.02 \%$ \\
\hline Total & & 297 & $100 \%$ \\
\hline
\end{tabular}

From the data provided in the table above, it can be seen that the most frequently translation strategy used is translation by paraphrase with 220 total of occurrences, while the less frequently translation strategy used is translation by using idiom of similar meaning form with 6 total of occurrences.

\section{Translation by Paraphrase}

This is by far the most common way of translating idioms when it seems inappropriate to use idiomatic language in the target text because of differences in stylistic preferences of the source and target language. The following is the example of translation strategy by paraphrase:

ST: When he looks in the water, he sees the face of his little girl, and he breaks down and cries right there.

TT: Ketika melihat ke dalam air, ia melihat wajah putri kecilnya. Hatinya langsung luluh, dan ia menangis di tempat itu. 
BT: When he looked into the water, he saw the face of his little daughter. His heart was immediately melted, and he cried in that place.

The source text in the example above contains an idiom breaks down and cries. The idiom break down and cry means to cry after losing control of one's emotions, especially after trying not to or after an intense buildup. Breaks down and cries is translated into hatinya langsung luluh, dan ia menangis. It does not belong to Indonesian idiom, but shows the meaning of idiom breaks down and cries.

\section{Using Idiom of Similar Meaning but Dissimilar Form}

Translation by using idiom of similar meaning but dissimilar form means that the idiom or expression in the source text is translated into the target language by using idiom or expression in the target language which has the same meaning with the idiom or expression in the source text but in different lexical items. The following is the example of translation strategy by using similar meaning but dissimilar form:

ST: It's not that Jamie was unattractivedon't get me wrong.

TT: Itu tidak berarti bahwa Jamie tidak menarik-jangan salah sangka.

BT: I doesn't mean that Jamie was not interesting-don't get me wrong.

The source text in the example above contains idiomatic expression don't get me wrong. The idiomatic expressions don't get me wrong has meaning don't misinterpret what I'm saying as criticism. It is translated into jangan salah sangka in the target language which has meaning don't take it wrong. Both don't get me wrong and jangan salah sangka have the same meaning but they have different lexical items.

\section{Translation by Omission}

The omission strategy is occurred when the translator chooses not to translate the idioms because the equivalent is not available in the target language, the meaning is not easy to be paraphrased and it is omitted because of the stylistic reasons. The following is the example of translation strategy by omission:

ST: My ancestors, so to speak.

TT: Lukisan-lukisan nenek moyangku.

BT: Paintings of my ancestors.

The idiom so to speak is a phrase to indicate that what one has just said is an uncommon, metaphorical, or original way of saying something. This idiom is similar to the phrases 'ifyou will' and 'in a manner of speaking'. The translator omits the idiom instead of translating it into bisa dibilang or boleh dikatakan.

\section{Using Idiom of Similar Meaning Form}

This strategy involves using an idiom in the target language which conveys roughly the same meaning as that of the source language idiom and, in addition, consist of equivalent lexical items (Baker, 1992, p.72). The example of translation strategy using an idiom of similar meaning form is expressed below:

ST: There are moments when I wish I could roll back the clock and take all the sadness away, but I have the feeling that if I did, the joy would be gone as well.

TT: Ada saat-saat aku berharap dapat memutar kembali jarum jam dan meniadakan semua kesedihan di sana. Namum perasaanku mengatakan bahwa kalau aku melakukannya, saat yang menyenangkan juga akan ikut hilang.

BT: There are times I wish I could roll back the time and eliminate all the sadness there. But my feeling says that if I do it, the good time will also disappear.

In the example above, the idiom roll back the clock is translated into memutar kembali jarum jam. The idiom roll back the clock means revisit, recount, return to or recreate a time or era from the past. It is translated into memutar kembali jarum jam which means to go back to the past. Both roll back the clock and memutar kembali jarum jam have similar meaning and the same lexical items.

\section{The Realization of Degree of Equivalence}

There are 297 idiomatic expressions analyzed. According to the result of the analysis, it is found that 159 data are categorized as fully 
equivalent (FE), 108 data are categorized as nonequivalent with different meaning (DIFM), 15 data are categorized as partly equivalent with increased meaning (IM), 11 data are categorized as non-equivalent with no meaning (NOM) and 4 data are categorized as partly equivalent with decreased meaning (DM). The following table shows the amount of translation which categorized as either complete meaning, increased meaning, decreased meaning, different meaning or no meaning.

Table 2. Frequency of Meaning Equivalences

\begin{tabular}{llll}
\hline No. & $\begin{array}{l}\text { Degree } \\
\text { Equivalence }\end{array}$ & $\begin{array}{l}\text { of } \\
\text { cy }\end{array}$ & $\begin{array}{l}\text { Percenta } \\
\text { ge }\end{array}$ \\
\hline 1. & FE & 159 & $53.53 \%$ \\
2. & DIFM & 108 & $36.36 \%$ \\
3. & IM & 15 & $5.05 \%$ \\
4. & NOM & 11 & $3.70 \%$ \\
5. & DM & 4 & $1.34 \%$ \\
\hline Total & & 297 & $100 \%$ \\
\hline
\end{tabular}

From the data provided in the table above, it can be seen that the most frequently degree of equivalence appeared is fully equivalent (FE) with 159 total of occurrences, while the less frequently degree of equivalence appeared is partly equivalent with decreased meaning (DM) with 4 total of occurrences.

\section{Fully Equivalent (Complete Meaning)}

Complete meaning occurs if the meaning in the source text is transferred completely into the target language. The following is the example of the translation which have complete meaning:

ST: "You'll be graduating in June, and I think it would look good on your record. Your mother thinks so, too, by the way."

TT: "Kau akan lulus bulan Juni, dan menurutku itu bagus untuk catatanmu. Omongomong, ibumu juga berpendapat sama."

BT: "You will graduate in June, and I think it's good for your record. By the way, your mother also thinks the same."
The source text in the example above contains an idiomatic expression by the way. By the way is a phrase indicating that the speaker is adding information. The translator translates it into omong-omong. The phrase omong-omong has the same function and sense of language as the idiom by the way. Hence, the translation has complete meaning.

\section{Non Equivalent with Different Meaning}

Different meaning occurs if the translator adds information in the source text with the words which have different meaning in the target language. The following is the example of the translation which have different meaning:

ST: She'd probably listen to Carey's squeaky voice, see the goodness radiating from his heart, and accept right off the bat.

TT: Ia mungkin mau mendengarkan suara melengking Carey, melihat kebaikan yang terpancar dari dalam hati cowok itu dan menerima semua kekurangannya.

BT: She probably wanted to listen to Carey's shrill voice, seeing the kindness that emanates from his heart and accept all his shortcomings.

The source text of the example above contains an idiom right off the bat which has meaning immediately; without delay. It is translated into semua kekurangannya (accept all his shortcomings) which has totally different meaning from the idiom right of the bat. Therefore, the translation above is considered to be non-equivalent with different meaning.

\section{Partly Equivalent with Increased Meaning}

Increased meaning occurs when there is additional information realized by new meaning which is not found in the source text. The following is the example of the translation which have increased meaning:

ST: He was the one, by the way, want you imagine him as the sort of man who slaved over his business, working diligently and watching it grow, prospering slowly overtime.

TT: Omong-omong, dialah yang menjadikan keluarga kami kaya-raya, tapi aku tidak ingin kau 
membayangkan dirinya sebagai orang yang banting tulang mati-matian dalam bekerja, dan menumpuk kekayaannya perlahan-lahan.

BT: By the way, it was he who made our family wealthy, but I didn't want you to imagine himself as someone who slammed his bones desperately at work, and accumulated his wealth slowly.

The source text of the example above contains an idiom slaved over which has meaning to spend a lot of time working strenuously and continuously on or at something. The translator translates it into banting tulang which means to work earnestly to achieve the desired goals that are sometimes too excessive so that it can have a negative impact on the person. The translator also adds an adverb mati-matian (desperately) in translating the idiom. Thus, it can be concluded that the translation above is categorized as partly equivalent with increased meaning.

\section{Non Equivalent with No Meaning}

No meaning occurs if the translator does not realize the translation of the words and idiom in the source text, so the target language loses all information contained in the source text. The following is the example of the translation which have no meaning:

ST: He could throw a baseball at almost ninety miles an hour, and he'd led the football team to back-to-back state titles as the star quarterback.

TT: Ia dapat melempar bola baseball dengan kecapatan sekitar $140 \mathrm{~km}$ per jam, dan sebagai gelandang ia membawa tim football kami ke peringkat nasional.

BT: He could threw a baseball with a speed of around $140 \mathrm{~km}$ per hour, and as a midfielder he took our football team to the national rank.

In the example above, the source text contains an idiom back-to-back which has meaning happening one after another, without interruption. The translator does not translate the idiom back-to-back in the target language, but instead omit it. This makes the target language loses all information of the idiom back-to-back. The source text should be translated into "... sebagai gelandang ia membawa tim football kami ke peringkat nasional secara berturut-turut." Hence, the translation above is categorized as nonequivalent with no meaning.

\section{Partly Equivalent with Decreased Meaning}

Decreased meaning occurs if some of the meaning in the source text is not realized in the target language. The following is the example of the translation which have decreased meaning:

ST: The policemen in our town had the most boring jobs in the world, but they still liked to strut around with a swagger or sit in coffee shops while they talked about the "big crime," as if they'd cracked the case of the Lindbergh baby.

TT: Para polisi di kota kami menjalani tugastugas yang paling membosankan di dunia ini, namun mereka masih suka berlagak sok jago sambil membawa-bawa pentungan atau duduk-duduk di kedai kopi sambil membahas soal "kejahatan besar" itu, seakan mereka telah berhasil suatu misteri seheboh kasus penculikan bayi keluarga Lindbergh.

BT: The police in our city were carrying out the most tedious tasks in the world, but they still liked to pretend to be good at carrying batons or sitting in coffee shops while discussing the "big crime", as if they have succeeded in a mystery as bad as the kidnapping of the baby of the Lindbergh family.

The source text in the example above contains an idiom strut around which has meaning to walk around (some place) in a vain, swaggering, or pompous manner. It is only translated into berlagak sok jago which has meaning to act like a good ass. This reduces the information walk around contains in the idiom strut around. Thus, the translation above is categorized as partly equivalent with decreased meaning.

\section{Relation between Translation Strategy Used and Degree of Equivalence}

The result of the analysis shows that when the translator employed the strategy of using idiom of similar meaning form, the translations are categorized into fully equivalent. When the translator employed the strategy of using idiom of similar meaning but dissimilar form, most of the 
translations are categorized into fully equivalent, however one of them is categorized as into partly equivalent with increased meaning, and another one is categorized into non-equivalent with different meaning. When the translator translates idiomatic expressions by using strategy of translation by paraphrase, the result of the idiomatic translations have many variations of degree of equivalence. From 220 data which are translated by using this strategy, 95 translations are categorized into fully equivalent, 14 translations are categorized into partly equivalent with increased meaning, 4 translations are categorized into partly equivalent with decreased meaning, and 107 translations are categorized into non-equivalent with different meaning. While when the translator translates the idiomatic expressions by using strategy of translation by omission, the result shows that the idiomatic translations are categorized into nonequivalent with no meaning. The following table shows the detail results.

Table 3. Relation between Translation Strategy and Degree of Equivalence

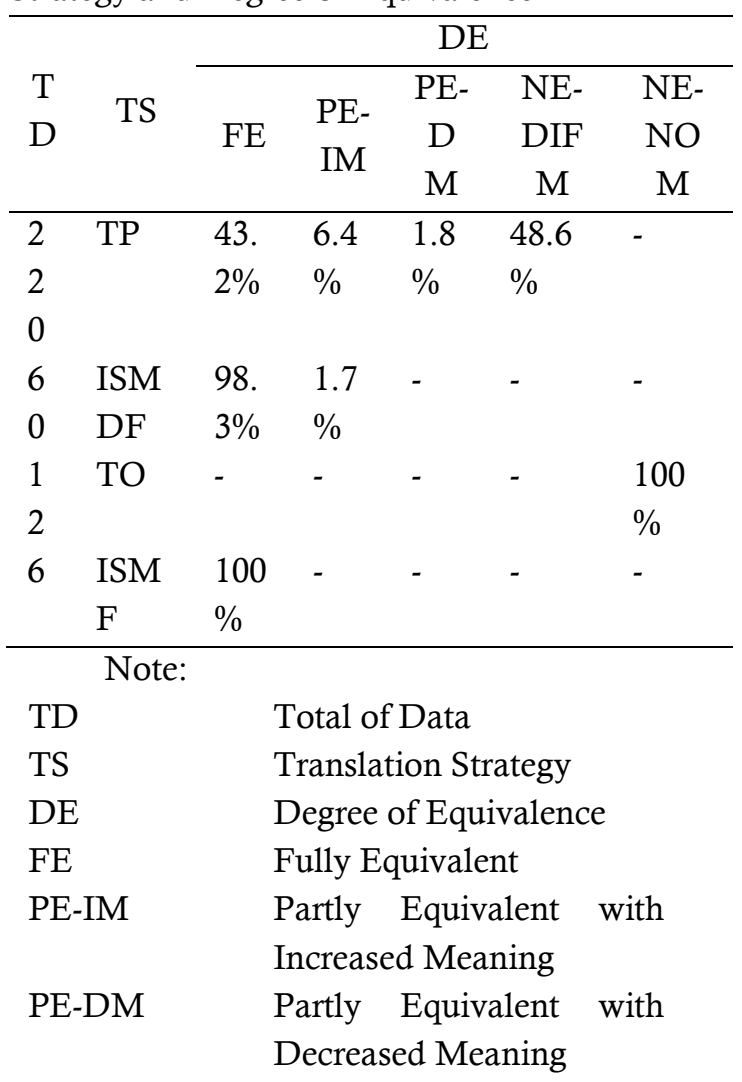

$\begin{array}{ll}\text { NE-DIFM } & \begin{array}{l}\text { Non-Equivalent with } \\ \text { Different Meaning }\end{array} \\ \text { NE-NOM } & \begin{array}{l}\text { Non-Equivalent with No } \\ \text { Meaning }\end{array} \\ \text { TP } & \text { Translation by Paraphrase } \\ \text { ISMDF } & \text { Using Idiom of Similar } \\ & \text { Meaning but Dissimilar } \\ & \text { Form } \\ \text { TO } & \text { Translation by Omission } \\ \text { ISMF } & \text { Using Idiom of Similar } \\ & \text { Meaning Form }\end{array}$

Referring to the table above, this research concludes that the best option for translating idiomatic expressions is by implementing the strategy of using idiom with similar meaning and form, due to the fact that all of the translation with that strategy resulting in fully equivalent meaning. However, not every idiom of the source language is available in the target language, in that case the alternative for translators to produce fully equivalent translation is the strategy of using idiom with similar meaning but dissimilar form. In the most extreme situation when the idiomatic expressions of the source language do not have available idiom with similar meaning in the target language, translators may use the strategy of translation by paraphrase, but the translators need to be very careful when using this strategy. Based on this research, there are $48.63 \%$ out of 220 data that uses strategy of translation by paraphrase resulting in non-equivalent with different meaning. In addition, translators must also be careful when using the strategy of translation by omission, since this strategy might be resulting in the loss of information contained in the source text.

\section{CONCLUSION}

Based on the results of the analysis, the conclusion can be drawn as follows. The analysis on the translation strategies employed by the translator shows that there are four strategies suggested by Baker used in translating idiomatic expressions found in Nicholas Sparks' $A$ Walk to Remember, with strategy of translation by paraphrase as the most dominant one, followed 
by using idiom of similar meaning but dissimilar form, translation by omission and using idiom of similar meaning form.

In terms of degree of equivalence between English original version and the Indonesian translation, from 297 data, most of the data are categorized as fully equivalent, followed by nonequivalent with different meaning, partly equivalent with increased meaning, nonequivalent with no meaning and lastly partly equivalent with decreased meaning.

The translation strategy used in translating idiomatic expressions affects on the degree of equivalence. When the translator employed the strategy of translation by using idiom of similar meaning form, it makes the idiomatic translations have complete meaning. When the translator employed the strategy of translation by using idiom of similar meaning but dissimilar form, most of the idiomatic translations have complete meaning, one of them has increased meaning, and one another has different meaning. When the translator employed the strategy of translation by paraphrase, it makes the idiomatic translations could have complete meaning, increased meaning, decreased meaning or different meaning. While when the translator employed the strategy of translation by omission, it makes the idiomatic translations have no meaning.

\section{REFERENCES}

Adelnia, A. \& Dastjerdi, H.V. (2011). Translation of Idioms: A Hard Task for the Translator. Finland: Academy Publisher.

Baker, Mona. (1992). In Other Words: A Coursebook of Translation. New York: Routledge.

Bell, Roger T. (1991). Translation and Translating. London: Longman Group UK Limited.

Catford, J.C. (1965). A Linguistic Theory of Translation. London: Oxford University Press.

Imanudin, Fathan. (2018). An Analysis of Idioms in Nobokov's "Lolita" and Their Translation in Kurnia's "Lolita". English Language \& Literature Journal. Vol. VII(4) 2018. page 357-366.

Larson, Mildred L. (1984). Meaning-Based Translation: A Guide to Cross Language Equivalence. Boston: University of America.
Massoud, M. (1988). Translate to Communicate: A Guide for Translators. Colorado: David C. Cook Foundation.

Nababan, Rudolf. (1999). Teori Menerjemah Bahasa Inggris. Yogyakarta: Pustaka Pelajar.

Saputri, Agnetia D. (2014). Strategies in the Translation of Breaking Dawn by Stephenie Meyer. Final Project UNNES Semarang.

Sparks, N. (1999) A Walk to Remember. New York: Grand Central Publishing.

Sparks, N. (2002) A Walk to Remember (Kan Kukenang Selalu) translated by Kathleen SW. Jakarta: PT Gramedia.

Winarto, L. \& Tanjung, S. (2015). An Analysis of English Idiomatic Expressions in "Transformer III-Dark of The Moon": The Translation Strategies and Their Degree of Meaning Equivalence. BASTER: Bahasa, Sastra, dan Terjemahan. Vol. I(1) 2015. page 20-34. 